\title{
Peran Lembaga Pendidikan Dalam Pengarusutamaan Islam Moderat Sebagai Upaya Melawan Paham Konservatif-Radikal
}

\author{
Amin Maghfuri ${ }^{1}$ \\ ${ }^{1}$ Universitas Islam Negeri Sunan Kalijaga Yogyakarta \\ maghfuri7393@gmail.com
}

\begin{abstract}
Keywords:

moderate islam; conservativeism; religious moderation; educational institutions.

In recent years, the landscape that shows a conservative tendency in religion has increased significantly. The Islamic Conservatives in Indonesia experienced unexpected and quite surprising growth and development, and perhaps reached its peak in the last 3-5 years. The negative excesses of this conservative tendency are quite worrying and have the potential to disrupt the sustainability of democracy and the integrity of the nation. This research seeks to elaborate efforts to mainstream moderate Islam which is the main agenda of the government (Ministry of Religion) as a step to counter conservative understanding and see how the role of educational institutions there. This research is a qualitative research focusing on the literature study and using a descriptive-analysis approach. The results of this study indicate that in an effort to mainstream moderate Islam, educational institutions play a significant role although not the only determinant. This role can be realized through several aspects such as curriculum and learning processes in educational institutions, supervision and guidance of programs or activities outside the curriculum of educational institutions starting from elementary to high levels, as well as through educational institutions policies.
\end{abstract}

\section{Abstrak:}

Kata Kunci:
islam moderat; paham konservatif; Dalam beberapa tahun terakhir, pemandangan yang menampakkan kecenderungan konservatif dalam beragama mengalami peningkatan yang cukup signifikan. Kelompok konservatif Islam di Indonesia mengalami pertumbuhan dan perkembangan yang barangkali tidak terduga dan cukup mengagetkan, dan barangkali mencapai puncaknya pada 3-5 tahun terakhir. Ekses negatif dari kecenderungan konservatif tersebut cukup mengkhawatirkan dan berpotensi mengganggu keberlangsungan demokrasi serta keutuhan bangsa. Penelitian ini bertujuan untuk mengelaborasi 
upaya pengarusutamaan Islam moderat yang menjadi agenda utama pemerintah (Kemenag) sebagai langkah meng-counter pemahaman konservatif serta melihat bagaimana peran lembaga pendidikan di dalamnya. Penelitian ini merupakan penelitian kualitatif dengan memfokuskan pada kajian literatur serta menggunakan pendekatan deskriptif-analisis. Hasil penelitian ini menunjukkan bahwa dalam upaya pengarusutamaan Islam moderat, lembaga pendidikan memainkan peran yang cukup signifikan meski bukan satu-satunya penentu. Peran tersebut dapat diwujudkan melalui beberapa aspek seperti kurikulum dan proses pembelajaran di lembaga pendidikan, pengawasan dan pembinaan program atau kegiatan di luar kurikulum lembaga pendidikan mulai tingkat dasar sampai perguruan tinggi, serta melalui kebijakan lembaga pendidikan.

Received : 13 November 2019; Revised: 02 Desember 2019; Accepted: 12 Desember 2019

(C) Tadris Jurnal Pendidikan Islam http://doi.org/10.19105/tjpi.

Institut Agama Islam Negeri Madura, Indonesia

This is an open access article under the CC-BY-NC license

\section{Pendahuluan}

Sepanjang beberapa dekade terakhir, khususnya pasca-lengsernya rezim Orde Baru pada tahun 1998, Indonesia mengalami berbagai dinamika kebangsaan terutama yang berkaitan dengan kondisi sosial-politik. Tumbangnya rezim Orde Baru yang dinahkodai oleh Soeharto dan diikuti dengan gerakan reformasi secara radikal merubah tatanan sosial-politik yang berlangsung dalam masyarakat. Era baru reformasi menjadi angin segar bagi masyarakat untuk keluar dari keterkungkungan yang mereka alami dimasa otoriter Orde Baru. Maka tidak mengherankan jika sejak era reformasi dimulai, beragam ekspresi kebebasan ditampilkan oleh hampir semua lapisan masyarakat yang rindu akan hak demokrasinya. Era baru reformasi dianggap sebagai moment yang tepat untuk mengembalikan semangat dan praktik demokrasi di Indonesia setelah sebelumnya mengalami disorientasi.

Diantara tuntutan yang paling utama di era reformasi adalah dibukanya keran kebebasan masyarakat dengan seluas-luasnya di semua aspek kehidupan mereka. Setelah sebelumnya mereka dibungkam dan kebebasan mereka dikekang, peralihan menuju era demokrasi yang sesungguhnya merupakan angin segar bagi kehidupan bernegara. Namun tidak jarang peralihan ini justru terjadi dari satu titik ekstrim ke titik ekstrim lainnya sehingga menimbulkan ekses-ekses negatif dalam proses tersebut. Meski demikian, upaya-upaya menampilkan wujud demokrasi yang lebih nyata pasca-Orde Baru dapat dikatakan baru dimulai saat lahirnya reformasi. Upaya ini, yang disebut dengan demokratisasi, terus berlangsung sampai sekarang dalam rangka menemukan format yang relevan dan compatibel dengan konsidi di Indonesia.

Keran kebebasan yang terbuka lebar sejak era reformasi ini mengizinkan terbentuknya berbagai gelombang baru dalam masyarakat sebagai ekspresi kebebasan mereka. Salah satu gelombang baru yang muncul adalah gelombang menguatnya semangat dalam menampilkan keagamaan yang ditunjukkan oleh sebagian kelompok muslim dengan mengemukanya berbagai organisasi dan lembaga baru yang berbasis keislaman. Beberapa di antara organisasi dan lembaga baru tersebut adalah gerakan Tarbiyah, Hizbut Tahrir Indonesia ( $\mathrm{HTI})$, 
Majelis Mujahidin Indonesia (MMI), Front Pembela Islam (FPI) dan lain sebagainya. ${ }^{1}$ Massifnya kemunculan organisasi dan lembaga baru yang berbasis keislaman ini membentuk gelombang baru islamisasi ${ }^{2}$ yang cukup besar mendampingi proses demokratisasi. Pada gilirannya, dua gelombang besar ini tidak jarang mengalami dialektika yang saling melengkapi, bersinggungan dan bahkan juga ketegangan satu sama lain. Kenyataan bahwa Indonesia merupakan negara dengan mayoritas penduduk muslim turut berperan dalam dinamika dan pergolakan yang terkait dengan demokratisasi dan islamisasi yang berlangsung di Indonesia. Dinamika tersebut bahkan dapat dikatakan sebagai ciri khas proses demokratisasi di Indonesia yang tidak terjadi di negara lain.

Demokratisasi merupakan upaya-upaya konstitusional yang dilakukan oleh pemerintah dan warga masyarakat dengan tujuan menciptakan kehidupan sosial-politik yang lebih demokratis. Upaya ini telah berjalan sejak era reformasi dimulai, terbukti dengan semakin menguatnya penerapan unsur-unsur yang menguatkan demokrasi. Sedangkan islamisasi disini dipahami bukan sebagai upaya pengislaman atau sejenisnya, akan tetapi lebih kepada upaya-upaya penerapan syari'at Islam sebagai hukum formal negara atau formalisasi syariat islam dengan memaksakan untuk menampakkan segala sesuatu dengan tampilan yang islami/syar'i. Pergulatan demokratisasi dan islamisasi dalam diskursus sosial-politik di Indonesia pada awalnya tidak ada pertentangan yang mencolok, namun gelombang tersebut secara tidak langsung dan pada titik-titik tertentu mengakibatkan polarisasi yang cukup mencolok antar warga negara, khususnya dominasi muslim terhadap yang lainnya.

Perkembangan dan konsekuensi dari proses Islamisasi tersebut menunjukkan adanya arus yang berlawanan dengan semangat demokratisasi yang terus berjalan. Demokratisasi yang memiliki tujuan terciptanya kehidupan berbangsa dan bernegara yang demokratis di satu sisi mengharuskan atau menjamin berlangsungnya proses Islamisasi tersebut. Namun di sisi lain, islamisasi yang berlangsung semakin hari semakin menunjukkan arus yang berlawanan dan terkadang justru mencederai semangat demokratis itu sendiri. Seringkali, cara-cara yang digunakan dalam proses islamisasi tersebut adalah dengan paksaan atau bahkan kekerasan yang berlawanan dengan prinsip-prinsip demokrasi. $^{3}$

Bermunculannya organisasi atau lembaga berbasis Islam yang antimainstream dengan mengusung pemahaman Islam yang fundamentalis dan konservatif terbukti membawa preseden buruk bagi keberlangsungan kehidupan yang harmonis dan demokratis antar sesama warga negara. Bibit-bibit fundamentalisme dan konservatisme, meskipun tidak dapat disimpulkan secara langsung, mengarahkan pada ekstrimisme dan aksi-aksi intoleran dalam bentuk teror atau yang lainnya. Beberapa aksi intoleran dan kekerasan telah terbukti banyak dilakukan oleh kelompok-kelompok yang berafiliasi pada organisasi yang berhaluan fundamentalis ataupun konservatif, baik yang memiliki tujuan sekedar menerapkan hukum Islam (syariat) dengan lebih ketat (formalisasi hukum Islam) atau bahkan sampai dengan tujuan mendirikan Khilafah Islamiyah yang berarti mengganti ideologi pancasila.

\footnotetext{
${ }^{1}$ M. Imdadun Rahmat, Arus Baru Islam Radikal: Transmisi Revivalisme Islam Timur Tengah ke Indonesia, (Jakarta: Erlangga, 2005), hlm. 75-76.

${ }^{2}$ Sri Yunanto, Islam Moderat vs Islam Radikal; Dinamika Politik Islam Kontemporer, (Yogyakarta: Media Pressiondo, 2018), hlm. 97.

3 Sumanto Al Qurtuby, "Pacifying The Radicals: Religiuos Radicalism, Islamist Militancy and Peacebuilding Approaches in Contemporary Indonesia" Journal of Southeast Asian Studies, Volume 24(1), 2019, hlm. 4.
} 
Dengan jumlah populasi penduduk muslim terbesar di dunia, sejujurnya Indonesia digadang-gadang sebagai model bagi pengembangkan paham Islam moderat yang dapat dengan harmonis berdampingan dengan penganut agama lain, dapat mengakomodir kekayaan budaya serta kompatibel dengan sistem demokrasi. Barangkali tidak salah jika berdasarkan alasan tersebut dan juga perkembangan demokrasi yang berlangsung di Indonesia sejauh ini, Islam di Indonesia dapat dijadikan sebagai role model bagi implementasi demokarasi di negara-negara muslim lainnya. ${ }^{4}$ Namun demikian, perjalanan dan pesandingan antara demokrasi dan Islam di Indonesia terus mengalami dinamika sejak awal reformasi sampai sekarang. Belakangan justru tantangan-tantangan yang berusaha menghambat laju demokratisasi di Indonesia kian menguat keberadaannya. Tantangan-tantangan yang semakin hari semakin meresahkan tersebut dapat dilihat dari maraknya pemahaman fundamental dan konservatif yang menjurus ke arah radikalisme bahkan juga usaha mengganti falsafah pancasila dengan perjuangan pendirian khilafah. Hal-hal tersebut menjadi sandungan yang harus dilalui dan tentu bukanlah sesuatu yang mudah untuk dilewati dalam agenda demokratisasi di Indonesia.

\section{Konservatisme Agama dan Tantangan Demokrasi}

Kesepakatan final terkait dengan bentuk dan dasar negara diantara para founding father menghendaki Indonesia bukan sebagai negara Islam ataupun negara sekuler, melainkan negara demokrasi dengan berlandaskan pansasila. Pancasila merupakan lima prinsip dasar yang harus menyertai setiap laju perkembangan bangsa sebagai ruh perkembangan tersebut. Pancasila menjadi pembeda bagi pengimplementasian demokrasi yang berlangsung di negaranegara lain sehingga tidak terjerumus pada demokrasi sekuler, yang terpisah dengan nilai-nilai agama. Di dalam pancasila terkandung nilai-nilai demokrasi yang bukan hanya tidak bertentangan dengan nilai-nilai Islam, tetapi juga menunjukkan semangat yang sama dan kompatibel dengan nilai-nilai Islam. ${ }^{5}$ Nilai-nilai demokrasi sendiri yang memuat semangat persamaan, kebebasan, hak asasi manusia serta musyawarah merupakan semangat yang diajarkan oleh Nabi Muhammad Saw. ketika memimpin Madinah. Hal tersebut khususnya bisa dilihat dan dicermati dari Piagam Madinah (al-Shahifat al-Madinah) yang memuat dasardasar kehidupan bersama masyarakat Madinah. ${ }^{6}$

Belakangan, muncul kelompok-kelompok yang mempertanyakan sistem yang telah mapan di Indonesia dan berusaha menggantinya dengan apa yang mereka anggap sebagai yang dikehendaki Islam. Kemunculan kelompok tersebut mulai menunjukkan ancamannya terhadap demokrasi dalam berbagai kesempatan, mulai dari aksi-aksi keagamaan yang berbau politik sampai penggunaan kekerasan. Gelombang baru keberislaman yang muncul pada masyarakat muslim Indonesia menunjukkan adanya kecenderungan konservatif yang berkemungkinan besar mengarah pada fundamentalisme dan bahkan radikalisme.

Konservatisme sebagai sebuah pemahaman dan praktik agama konservatif merupakan pemahaman yang berpegang secara ketat pada kitab suci atau pada ajaran, ortodoksi dan tradisi yang dianggap sebagai paling benar. ${ }^{7}$

\footnotetext{
${ }^{4}$ Muhammad Zuhdi, "Challenging Moderate Muslim: Indonesia's Muslim School in the Midst of Religious Conservatism” Journal Religions, 2018, hlm. 12.

${ }^{5}$ Sri Yunanto, Islam Moderat..., hlm. 37-38.

${ }^{6}$ Ayang Utriza Yakin, Islam Moderat dan Isu-Isu Kontemporar, (Jakarta: Kencana, 2016), hlm. 12 17.

Azyumardi Azra, "Konservatisme Islam", dalam Republika.co.id, diakses pada senin 30
} 
Pemahaman ini umumnya sepaket dengan penolakannya terhadap bentukbentuk penafsiran baru yang modern, liberal atau progresif yang berkenaan dengan ajaran Islam. Spektrum ekstrim dari konservatisme ini sering muncul dalam bentuk fundamentalisme agama yang sering digunakan untuk mewujudkan aganda religio-politik. Orientasi keislaman dan kecintaan baru pada Islam diekspresikan dengan adopsi ketaatan baru pada ibadah-ibadah Islam dan ditunjukkan dengan mewujudkan gaya hidup yang mereka anggap lebih Islami. Sebagian dari mereka kemudian belajar dan mendapatkan pengajaran tentang Islam dengan lebih kaku dan rigit yang kemudian disebut dengan kaum konservatif.

Menurut Van Bruinessen, terdapat tiga sebab yang memungkinkan tumbuhnya trend Islam konservatif di Indonesia, sebagaimana dikutip oleh Zuhdi, ${ }^{9}$ yaitu bahwa pada dasarnya sebagian besar masyarakat muslim di Indonesia memang telah memiliki pandangan yang konservatif, penyokong pemahaman Islam moderat merubah agenda mereka menjadi agenda politik sehingga melemahkan promosi Islam moderat itu sendiri, serta terus meningkatnya pengaruh Islam Timur Tengah yang mengusung ideologi konservatif.

Sebetulnya, kategorisasi paham keislaman yang diantaranya meliputi konservatif, fundamentalis, ekstrimis, radikalis, salafis dan beberapa lainnya memiliki pengertian yang saling tumpang tindih dan seringkali memiliki maksud yang sama. Untuk mempermudah pemahaman, pemakaian kata tersebut disini akan diperjelas agar tidak menimbulkan kerancauan. Konservatif, fundamentalis dan salafi pada dasanya menunjukkan satu makna yang sama, atau setidaktidaknya berada pada jalur yang sama. Yang membedakan hanyalah sekedar level yang barangkali sedikit berbeda, namun seringkali pemakaiannya juga masih rancu. Tiga kata ini digunakan sebagai kategorisasi berdasarkan pemahaman terhadap doktrin. Sedangkan ekstrimis atau radikalis lebih ditujukan sebagai kategorisasi berdasarkan aksi-aksi yang dilakukan dengan menggunakan kekerasan. Keduanya pun sebenarnya seringkali digunakan dengan tumpang tindih.

Dalam pembahasan ini, terminologi "konservatif" yang digunakan menunjukkan sebuah pemahaman yang diyakini oleh seseorang atau kelompok yang tidak hanya berhenti pada ranah pemahaman yang literalis dan enggan menerima perbedaan tafsir, namun juga mendorong seseorang atau kelompok untuk mendemonstrasikan pemahaman konservatif tersebut ke dalam perilaku atau tindakan yang mengarah pada kategori radikal. Hal ini sekaligus untuk memberikan batasan yang jelas cakupan konservatif yang dimaksud. Karena tidak dapat dipungkiri, organisasi keagamaan atau kelompok yang selama ini dicitrakan sebagai penyokong utama moderasi agama juga memiliki sisi-sisi konservatif. NU dan Muhammadiyah sebagai dua organisasi terbesar di Indonesia yang memiliki citra moderat, masing-masing juga mempunyai sisi liberal dan konservatif. ${ }^{10}$ Namun demikian, pemahaman konservatif dari dua organisasi ini tidak mengarah pada upaya-upaya formalisasi syariat yang dilakukan dengan cara-cara paksa dan bahkan kekerasan serta tidak mengarah pada semangat untuk mendirikan negara Islam dalam bentuk khilafah dengan

September 2019, pukul 15.45 WIB.

${ }^{8}$ Ibid.

${ }^{9}$ Muhammad Zuhdi, "Challenging..., HIm. 4.

${ }^{10}$ Martin Van Bruinessen (ed), Contemporary Development in Indonesian Islam: Explaining the Conservative Turn, (Singapore: ISEAS Publishing, 2013), hlm. 3-4. 
mengganti pancasila yang sejak awal disepakati sebagai prinsip dan falfasah negara.

Kecendrungan konservatif yang menjangkiti keberagamaan masyarakat muslim Indonesia telah menjadi kajian yang serius di kalangan ilmuan. Meski tesis yang diajukan Hefner menyatakan bahwa Islam Indonesia adalah Islam yang terbuka dan toleran -ia menggunakan istilah civil Islam ${ }^{11}$-, namun pada perkembangannya tesis tersebut ia sempurnakan dengan mengakui keberadaan atau bahkan perkembangan kelompok-kelompok Islam konservatif dan sejenisnya yang pada batas-batas tertentu kontras dengan tesis sebelumnya. ${ }^{12}$ Hal ini barangkali juga menunjukkan bahwa keberadaan kelompok-kelompok konservatif Islam mengalami perkembangan yang cukup signifikan sejak lengsernya Soeharto. Gerakan-gerakannya yang senyap sehingga tidak begitu jelas terlihat oleh banyak orang menjadi strategi yang jitu sampai kemudian mereka memiliki massa yang cukup besar dan mulai secara terang-terangan menampakkan keberadaannya di muka umum.

Kenyataan tersebut semakin menampakkan kebenarannya seiring berjalannya waktu. Indikasi menguatnya kelompok konservatif ini dapat dilihat dari berbagai bentuk, di antaranya menguatnya keinginan untuk menerapkan hukum Islam dengan ketat. Berdasarkan survey yang dilakukan pada tahun 2013 terhadap 39 negara dengan mayoritas penduduk muslim (dari total 48 negara) menunjukkan perbedaan level dalam mensupport pengimplementasian syariah sebagai hukum resmi negara. Di Indonesia, $72 \%$ menunjukkan keinginan penerapan syariah sebagai hukum resmi negara. ${ }^{13}$ Meskipun survey ini barangkali tidak sepenuhnya benar, mengingat jumlah mayoritas muslim toleran masih merepresentasikan muslim Indonesia, namun hasil survey tersebut patut dijadikan sebagai bahan refleksi dan peringatan bagi keberlangsungan Islam toleran di Indonesia.

Tren meningkatnya kecenderungan konservatif di kalangan muslim Indonesia juga dapat dilihat dari beberapa kasus yang melibatkan unsur politik. Misalnya saja dalam kasus pemilihan gubernur Jakarta 2017 maupun dalam kasus pemilihan umum presiden 2019. Pengerahan massa besar-besaran yang dilakukan berulangkali serta penggunaan atribut dan kata-kata yang bercirikan Islam dalam aksi-aksi tersebut secara jelas menampakkan keberhasilan kelompok konservatif Islam dalam memperoleh simpati dan memperluas pengaruhnya. Hal ini juga menunjukkan bahwa kelompok ini semakin hari semakin bagus dalam hal pengorganisasian, pendanaan dan keterlibatannya dalam agenda politik. ${ }^{14}$ Kebehasilan dalam pengerahan massa yang berlanjut dengan kemenangan calon yang didukung kelompok islamist pada pemilihan Gubernur Jakarta berpengaruh besar dan menjadi strarting point mengemukanya kelompok konservatif di daerah-daerah lain.

Pasca-dinamika politisasi Islam yang menemukan momentumnya pada Pilkada DKI 2017 -barangkali telah dimulai pada pemilu 2014-, intensitas kemunculan kelompok konservatif di hadapan publik menjadi kian sering. Kelompok ini juga semakin nyaring dalam bersuara dengan selalu

\footnotetext{
11 Lihat Robert W. Hefner, Civil Islam: Muslims and democratization in Indonesia, (Princeton: Princeton University Press, 2000).

12 Lihat Robert W. Hefner, "Whatever Happened to Civil Islam? Islam and Democratisation in Indonesia, 20 Years on", Asian Studies Review, 2019, DOI: 10.1080/10357823.2019.1625865.

${ }_{13}$ Alex. P Schmid, "Moderat Muslim and Islamist Terrorism: between Denial and Resistance" ICCT Research Paper, 2017, DOI: 10.19165/2017.1.09.

${ }^{14}$ Charlotte Setijadi, "Ahok's Downfall and the Rise of Islamist Populism in Indonesia" ISEAS Yusof Ishak Institute, No. 38 Issue : 2017, hlm. 1
} 
mengatasnamakan dirinya sebagai interpretasi dari masyarakat muslim secara umum. Entah kebetulan atau tidak, gelombang simpati dari berbagai daerah mengalir cukup deras pada aksi-aksi tersebut. Hal ini bisa jadi merupakan pukulan telak bagi masyarakat muslim atau organisasi keislaman yang menyokong berjalan dan berlakunya Islam moderat di Indonesia. Kemunculan kelompok konservatif dengan kuantitas yang cukup besar barangkali mengagetkan mereka, meski bukan sepenuhnya baru. Klaim dominasi muslim moderat secara tiba-tiba tergeser oleh nyaringnya kelompok konservatif yang dengan semangat terus menyuarakan keinginan serta tuntutannya.

Jika ditelusuri akar keberhasilan kelompok konservatif dalam menggalang kekuatan, menarik simpati serta memperluas pengaruhnya di kalangan muslim, tidak dapat dipungkiri pengaruh demokratisasi yang berjalan sejak lahirnya era reformasi memberikan dampak yang besar. Kebebasan berekspresi yang dijamin oleh hukum memberikan angin segar bagi keberlangsungan dan perkembangan kelompok konservatif. Meski tidak secara langsung menampilkannya ke ranah publik, perkembangan kelompok konservatif di Indonesia sebetulnya cukup berhasil. Terbukti dengan kesuksesan kelompok ini memasuki berbagai lini kehidupan dan berbagai jenis pekerjaan, serta puncaknya pada gelombang aksi masa yang berturut-turut dilakukan.

Selain itu, kehadiran gerakan transnasional Islam yang dibarengi dengan kebebasan dalam kerangka demokrasi memberikan pengaruh yang besar dalam merubah lanskip keislaman di Indonesia dan mampu mereduksi pengaruh besar NU dan Muhammadiyah. ${ }^{15}$ Gerakan ini lahir dan berkembang terutama di kampus-kampus umum dan mencapai kematangan setelah berdinamika sekian lama. Alumni-alumni gerakan kampus serta kembalinya beberapa lulusan dari Timur Tengah yang memiliki kecenderungan sama yang secara bersama-sama mengkampayekan pemahaman-pemahaman keagamaannya sehingga mampu menggaet banyak pengikut. Massifnya penyebaran pemahaman keagamaan oleh gerakan ini terbukti mampu menyaingi pengaruh NU dan Muhammadiyah bagi keberislaman masyarakat muslim di Indonesia.

Titik awal bahaya paham konservatif dan terutama yang disertai dengan tindakan-tindakan radikal adalah sikapnya yang tidak menerima perbedaan, baik perbedaan pemahaman, keyakinan dan lain sebagainya. Pada batas-batas tertentu pemahaman tersebut berpotensi besar mengganggu keharmonisan hubungan yang telah terjalin dari berbagai perbedaan yang ada di Indonesia. Adanya berbagai tindakan yang mengarah pada aksi radikalisme menjadi penyulut bagi keretakan hubungan antar individu, kelompok atau pemahaman yang berbeda-beda. Padahal, perbedaan-perbedaan tersebut merupakan sebuah kepastian yang tidak dapat dihindari. Upaya-upaya yang dilakukan untuk menghilangkan perbedaan, apalagi dilakukan dengan cara-cara yang provokatif dan kasar, justru akan membuat perbedaan tersebut menjadi bom waktu yang sangat berpotensi menghancurkan. Jika sudah demikian, maka demokrasi dan bahkan keberadaan negara akan menjadi rapuh dan pada puncaknya akan runtuh.

\section{Pengarusutamaan Islam Moderat dan Peran Lembaga Pendidikan}

Pemerintah, terutama melalui Kementerian Agama, memberikan respon terhadap meningkatnya pemahaman Islam konservatif dan fundamental dengan

\footnotetext{
${ }^{15}$ Martin Van Bruinnesen, "What Happened to the Smilling Face of Indonesian Islam? Muslim Intellectualism and the Conservative Turn in Post-Suharto Indonesia" RSIS Working Paper, 2011, hlm. 6.
} 
mewacanakan pengarusutamaan Islam moderat. Indonesia dengan mayoritas penduduk muslimnya memang dikenal sebagai negara muslim yang toleran yang dapat hidup berdampingan dengan berbagai jenis perbedaan. Namun setelah berbagai insiden kekerasan yang menyeret nama Islam terjadi, image sebagai negara muslim yang toleran mulai diragukan, atau setidaknya dipertanyakan. Rangkaian tindakan kekerasan sampai dengan aksi bom bunuh diri mengindikasikan bahwa Islam moderat yang telah lama menjadi ciri khas Islam Indonesia perlahan eksistensinya mendapat tantangan serius.

Meskipun Azyumardi Azra menyatakan bahwa Islam moderat di Indonesia adalah terlalu besar untuk runtuh/gagal (too big to fail), ${ }^{16}$ namun dibutuhkan tindakan nyata untuk memperkokoh eksistensi Islam moderat tersebut dalam rangka menghadapi arus pemahaman Islam yang sebaliknya. Tindakan nyata ini sekaligus untuk meneguhkan bahwasannya Islam moderat memang benar-benar dan akan terus menjadi karakter Islam yang ada di Indonesia. Tanpa adanya tindakan nyata untuk memperkokoh karakter tersebut, maka besar kemungkinan keberadaan Islam moderat di Indonesia akan tergeser dan digantikan oleh pemahaman Islam lain yang cenderung konservatif dan eksklusif.

Yang mengkhawatirkan adalah ketika pemahaman yang konservatif dan bahkan ekstrim mulai menyebar, arus utama pemahaman Islam yang moderat dan toleran justru semakin memudar dan semakin hari semakin "terdiam" sampai seolah-olah hanya kaum konservatif dan ekstirmis-lah yang bersuara dan merepresentasikan Islam dalam sikap dan tindakan mereka. Pemahaman Islam yang toleran dan moderat perlu dan penting untuk digaungkan dan disebarluaskan mengalahkan pemahaman yang lain. Namun demikian, hanya dengan mendeklarasikan bahwa Islam bukanlah agama kekerasan, radikal ataupun agama yang marah atau Islam adalah agama yang penuh kedamaian saja tidaklah cukup. Kita harus bertanggung jawab dan berperan dalam mendemonstrasikan dan menghidupkan bagaimana mengekspresikan Islam yang damai tersebut dalam kehidupan sehari-hari. ${ }^{17}$

Moderasi dalam beragama dirasa menjadi sesuatu yang vital bagi kelangsungan kehidupan berbangsa dan bernegara di Indonesia jika melihat kemajemukan yang ada. Moderasi penting karena keragaman dalam beragama, termasuk di dalamnya perbedaan pandangan dalam satu agama tertentu, merupakan suatu yang pasti dan mustahil dihilangkan. ${ }^{18}$ Upaya-upaya untuk menseragamkan dan mengeliminir keragaman merupakan tindakan yang sia-sia dan hanya akan membuang tenaga. Meski begitu, paham konservatif-radikal pada umumnya mendemonstrasikan tindakan tersebut, atau setidak-tidaknya mengarah kesana. Moderasi memberikan arahan agar pemahaman dan perilaku yang mengarah pada satu titik ekstrim tersebut menjadi lebih seimbang dan tengah-tengah. Perbedaan dan keragaman dalam konteks keseimbangan harus dilihat sebagai anugerah Tuhan sehingga tidak menimbulkan perpecahan di dalamnya. ${ }^{19}$

Moderasi dalam beragama tidak sama dengan sinkretisme maupun keberpihakan terhadap sikap liberal yang mengabaikan norma-norma dasar agama. Moderasi dapat dipahami sebagai cara pandang, sikap dan perilaku

\footnotetext{
${ }^{16}$ Azyumardi Azra, "Politik Islam Indonesia Kontemporer" dalam Sri Yunanto, Islam Moderat..., hlm. X.

${ }_{17}$ Alex. P Schmid, "Moderat Muslim..., hlm. 5.

18 Kementerian Agama RI, Moderasi Beragama, (Jakarta: Badan Litbang dan Diklat Kemenag RI, 2019), hlm. 8.

19 Muhlis M. Hanafi, Islamic Moderatism and Its Role in Empowering Harmony within Society, (Jakarta: Lajnah Pentashihan Mushaf Al Qur'an Balitbang dan Diklat Kemenag RI, 2016), hlm. 1.
} 
selalu mengambil posisi di tengah-tengah, selalu bertindak adil dan tidak ekstrem dalam beragama, baik ekstrem ke kanan maupun ekstrem ke kiri. $^{20}$ Kesalahpahaman terhadap makna moderasi seringkali menjadikan seseorang enggan untuk berperilaku moderat. Anggapan bahwa berperilaku moderat sama artinya dengan menggadaikan agamanya membuka peluang bagi seseorang untuk memegang pemahaman konservatif serta tertutup, dan pada level tertentu menghendaki sesuatu dengan menggunakan cara-cara intoleran. Padahal dengan moderasi, mereka akan dapat berinteraksi, berdialog serta menjadi terbuka dengan berbagai pihak baik yang berbeda agama, pemahaman maupun kultur sehingga sikap adil dan seimbang dapat mereka tampilkan. Sebab, tanpa adanya keterbukaan dan memilih menutup diri dengan orang lain dan lingkungan, mereka tidak akan mampu mengerti dan memahami orang lain sehingga mustahil dapat berlaku adil dan seimbang antar sesama. ${ }^{21}$

Untuk dapat menjadikan dan menguatkan sikap moderat dalam beragama sebagai fondasi keberagamaan masyarakat muslim di Indonesia, upaya pengarusutamaan moderasi beragama mutlak diperlukan. Pengarusutamaan moderasi beragama merupakan strategi yang dilakukan secara rasional dan sistematis untuk menjadikan cara pandang, sikap, dan perilaku beragama yang moderat sebagai perspektif dan landasan berfikir yang diterima bersama dalam membangun sumber daya manusia Indonesia. ${ }^{22}$ Pemerintah melalui Kementerian Agama telah melakukan beberapa strategi dalam upaya penguatan moderasi beragama ini, diantaranya: 1) sosialisasi dan desimenasi gagasan moderasi agama; 2) pelembagaan moderasi beragama ke dalam program dan kebijakan yang mengikat; serta 3) pengintegraasian perspektif moderasi beragama ke dalam rencana pembangunan jangka menengah nasional 2020-2024. ${ }^{23}$

Meski demikian, upaya-upaya tersebut tidak akan dapat berhasil jika hanya dilakukan secara individual, serampangan dan tidak sistematis. Upaya yang massif, sistematis dan terencana secara kelembagaan harus menjadi fondasi dasar pengarusutamaan Islam moderat di Indonesia, termasuk di dalamnya melalui pendidikan. Pendidikan menjadi salah satu sarana yang menentukan baik bagi perkembangan ataupun kemunduran penyebaran pahampaham konservatif-radikal. Berdasarkan beberapa hasil survey dan penelitian, pendidikan atau lembaga pendidikan hari ini menjadi salah satu tempat yang nyaman bagi perkembangan paham-paham konservatif-radikal. Kecenderungan akan penerimaan dan kesepahaman terhadap pemahaman-pemahaman konservatif-radikal tumbuh subur di lembaga pendidikan, terutama di tingkat SMA dan Perguruan Tinggi. ${ }^{24} \mathrm{Hal}$ tersebut tentu cukup mengkhawatirkan, mengingat sektor pendidikan merupakan medium yang memainkan peran kunci dalam menentukan kondisi sosial masyarakat, baik masa kini atau masa depan.

Dengan melihat posisi sentral serta peran vital yang dimiliki pendidikan, upaya pengarusutamaan Islam moderat memiliki peluang yang sama besarnya untuk dikembangkan dan disebarluaskan secara massif di dalamnya. Hal tersebut menuntut peran aktif lembaga pendidikan dalam mendiseminasikan pemahaman-pemahaman serta menanamkan nilai-nilai moderasi beragama

\footnotetext{
${ }^{20}$ Kementerian Agama RI, Moderasi..., hlm 17.

${ }^{21}$ Muhlis M. Hanafi, Islamic Moderatism..., hlm. 92.

${ }^{22}$ Kementerian Agama RI, Moderasi..., hlm. 104.

23 Ibid., hlm. 110.

24 Lihat di antaranya PPIM UIN Jakarta, "Ancaman Radikalisme di Sekolah", Policy Brief Series, Issue 4, Vol. 1 2018; LPPM UNUSIA, "Islam Eksklusif Transnasional Merebak di Kampus-Kampus Negeri", Ringkasan Laporan Penelitian, 2019; dan Setara Institute, "Wacana dan Gerakan Keagamaan di Kalangan Mahasiswa", Ringkasan Eksekutif, Mei 2019.
} 
dalam diri peserta didiknya. Upaya pengarusutamaan Islam moderat melalui lembaga pendidikan dapat diwujudkan melalui beberapa unsur, di antaranya:

a. Kurikulum dan proses pembelajaran

Terfasilitasinya kelompok-kelompok pembawa pemahaman konservatifradikal untuk menyebarkan pengaruh dan adanya infiltrasi pemahaman tersebut di dalam dunia pendidikan merupakan salah satu sebab berkembanganya paham konservatif-radikal di Indonesia. ${ }^{25}$ Di antara unsur yang sangat menentukan dalam infiltrasi pemahaman tersebut adalah kurikulum dan proses pembelajaran yang berlangsung di lembaga pendidikan. Kurikulum dan proses pembelajaran merupakan unsur yang mengarahkan peserta didik pada suatu pemahaman serta pada satu bentuk tertentu. Hal tersebut karena dalam penyusunan kurikulum, di dalamnya terjadi dinamika yang sangat komplek yang melibatkan kompromi, negosiasi, keputusan politik serta ideologi-ideologi dari berbagai belahan dunia. ${ }^{26}$

Pengarusutamaan moderasi beragama dapat dimulai dari tahap paling dasar dalam pendidikan, yaitu penyusunan kurikulum. Kurikulum pendidikan Islam harus diisi dengan konten-konten yang mengedepankan sikap ramah, terbuka, serta toleran. Hal tersebut harus dilanjutkan pada proses pembelajaran yang melibatkan pengajar, sehingga menuntut adanya pengajar yang memiliki pemahaman yang luas dan mengedepankan prinsip-prinsip moderat. Upaya ini memerlukan perhatian dan dukungan yang besar, terutama karena banyaknya jenis lembaga pendidikan serta luasnya wilayah Indonesia. Langkah awal telah dimulai oleh Kemenag dengan menerapkan standarisasi kurikulum pesantren sebagai upaya pengarusutamaan Islam moderat. ${ }^{27}$ Langkah ini harus didukung $^{2}$ dan diikuti oleh lembaga pendidikan lain seperti sekolah, madrasah atau perguruan tinggi sehingga upaya pengarusutamaan tersebut dapat berjalan maksimal.

b. Pengawasan dan pendampingan kegiatan di luar kurikulum pendidikan

Selain melalui kurikulum dan proses pembelajaran, infiltrasi pemahaman konservatif-radikal di sekolah juga berlangsung melalui saluran kegiatan di luar kurikuler. Kegiatan Rohani Islam di tingkat SMP dan SMA serta lembaga dakwah kampus di universitas secara umum didominasi oleh kelompok-kelompok konservatif. ${ }^{28}$ Kegiatan Rohis dan LDK di universitas merupakan arena yang digunakan sebagai sarana rekrutmen organisasi yang berpaham konservatif seperti gerakan tarbiyah, HTI dan salafi. Maka tidak mengherankan jika berbagai penelitian menyimpulkan bahwa sekolah dan kampus merupakan tempat tumbuh suburnya paham-paham eksklusif.

Untuk menunjukkan kepedulian sekaligus dalam upaya pengarusutamaan Islam moderat, lembaga pendidikan dituntut untuk mengawasi dan mendampingi berjalannya organisasi atau saluran yang digunakan sebagai sarana infiltrasi pemahaman konservatif seperti Rohis atau LDK. Hal tersebut dapat dilakukan misalnya dengan memonitoring secara berkala kegiatan-kegiatan yang dijalankan

\footnotetext{
${ }^{25}$ International NGO Forum on Indonesia Development, Urgensi dan Strategi Efektif Pencegahan Ekstremisme di Indonesia, (Jakarta: Infid, 2018), hlm. 4.

${ }^{26}$ Kathleen E. Woodward, "Indonesian School: Shaping the Future of Islam and Democracy in a Democratic Muslim Country" Journal of International Education and Leadership, Vol. 5 Issue 1 2015, hlm. 2.

27 Anonim, "Standardization of Pesantren aimed at Mainstreaming Moderate Islam", The Jakarta Post, diakses pada 14 Oktober 2019 pada pukul 05.30 WIB.

${ }^{28}$ LPPM UNUSIA, "Islam Eksklusif Transnasional Merebak di Kampus-Kampus Negeri”, Ringkasan Laporan Penelitian, 2019, hlm. 7.
} 
oleh organisasi tersebut, ikut terlibat dalam kegiatan atau mendorong organisasi yang berhaluan moderat untuk lebih aktif.

Sejalan dengan hal tersebut, lembaga pendidikan baik di sekolah maupun universitas perlu memfasilitasi individu-individu yang sedang mengikuti tren hijrah agar tidak terjerumus ke dalam pemahaman yang sempit. Hal ini penting karena berdasaran penelitian yang dilakukan oleh Aziz, pelaku hijrah umumnya memiliki pemahaman dan sikap yang tekstual dalam kaitannya dengan persoalan agama. ${ }^{29}$ Jangkauan wawasan dan penguasaan yang masih terbatas terhadap suatu persoalan tertentu, baik dikarenakan keengganan untuk mendalami satu tema tertentu atau karena masih dalam proses pencarian (belajar), umumnya mendorong individu untuk mengikuti pandangan-pandangan normatif atau literalis jika mereka dihadapkan pada persoalan-persoalan yang sensitif seperti toleransi, kesetaraan gender, HAM dan yang lainnya. Semangat keberagamaan yang sangat tinggi dan dibarengi dengan keengganan untuk terus memperluas wawasan keagamaan merupakan celah yang sangat mungkin menyebabkan pemahaman agama yang sempit, eksklusif dan intoleran. ${ }^{30}$ Ketika seseorang berada pada titik tersebut, kemungkinan untuk menjurus pada pemahaman fundamental atau bahkan radikal sangat terbuka lebar.

\section{c. Kebijakan lembaga pendidikan}

Berkembang pesatnya paham-paham eksklusif transnasional di sekolah dan universitas mengindikasikan kelemahan lembaga dalam membendung proses penyebaran paham tersebut. Menurut Halili sebagaimana dikutip Candra, lembaga pendidikan terkesan tidak peduli terhadap keberadaan dan perkembangan organisasi yang membawa paham eksklusif sehingga leluasa bergerak, terutama di kampus. ${ }^{31}$ Barangkali hal ini menjadi salah satu sebab organisasi yang berhaluan konservatif mampu merekrut banyak anggota dan mampu mendominasi di lingkungan kampus.

Dalam upaya pengarusutamaan Islam moderat, otoritas yang dimiliki oleh pimpinan suatu lembaga pendidikan harus diarahkan untuk mendorong terwujudnya pemahaman dan sikap yang moderat dan terbuka. Pimpinan lembaga dituntut ikut serta dalam upaya mengkampanyekan pemahaman Islam yang moderat melalui kebijakan-kebijakan yang dibuat. Hal tersebut dapat diwujudkan dalam berbagai bentuk seperti kebijakan yang dikeluarkan UGM dengan menghapus asistensi agama Islam yang pada praktiknya digunakan kelompok islam eksklusif untuk mendiseminasikan wacana dan doktrin keagamaannya, atau kebijakan berupa program deradikalisasi dalam bentuk pengisian jabatan penting dengan tokoh yang pluralis dan moderat yang dilakukan oleh UI. ${ }^{32}$

Pada level tertentu, kebijakan lembaga dapat digunakan sebagai sarana untuk memberikan sanksi atau bahkan mencabut izin suatu organisasi yang melanggar atau tidak sesuai dengan prinsip-prinsip negara Indonesia. Sebagai contoh, kebijakan pembekuan organisasi yang syiarkan negara khilafah yang

\footnotetext{
${ }^{29}$ Aziz asy'arie, "Studi Fenomenologi Pengalaman Hijrah Mahasiswa Universitas Gadjah Mada dan Implikasinya Terhadap Ketahanan Pribadi" Master Thesis, Pascasarjana UGM, 2019, hlm. 81.

${ }^{30}$ Abu Hafsin, dalam kata pengantar Kamdani (ed), Islam dan Humanisme: Aktualisasi Humanisme Islam di Tengah Krisis Humanisme Universal, (Yogyakarta: Pustaka Pelajar, 2007) hlm. vii.

${ }^{31}$ Candra Yuri Nuralam, "Kelompok Islam eksklusif Leluasa Bergerak di Kampus" medcom.com, diakses pada 14 Oktober 2019 pada pukul 06.00 WIB.

${ }^{32}$ International NGO Forum on Indonesia Development, Urgensi..., hlm. 8.
} 
dilakukan oleh organisasi HATI (Harmoni Amal dan Titian IImu) yang merupakan wujud lain dari HTI setelah dibubarkan. ${ }^{33}$

Upaya-upaya yang melibatkan otoritas pemegang kebijakan dalam rangka membendung dan meng-counter paham konservatif semacam ini sangat perlu dilakukan, baik ditingkat sekolah ataupun di universitas. Dengan adanya kebijakan yang pro terhadap upaya mengkampanyekan Islam moderat, maka secara tidak langsung lembaga pendidikan telah ikut serta dalam proses mewujudkan Islam yang moderat di Indonesia. Upaya ini juga diharapkan tidak berhenti sampai disitu saja, melainkan harus terus didorong dan ditingkatkan agar mampu mengatasi permasalahan konservatisme sampai pada akarnya.

\section{Kesimpulan}

Meningkatnya kecenderungan konservatif dalam beragama yang dialami masyarakat muslim Indonesia merupakan hasil dari dinamika yang berjalan sejak era reformasi. Kebebasan yang dijamin oleh konstitusi mengizinkan berbagai kelompok, termasuk yang berbasis transnasional, untuk berkembang di Indonesia. Lembaga pendidikan sebagai medium penyebaran pemahaman dan ideologi berperan penting bagi perkembangan dan meluasnya berbagai ideologi, baik yang konservatif ataupun yang moderat. Oleh karenanya, dalam upaya pengarusutamaan Islam moderat, pendidikan memiliki peran yang signifikan terutama berkaitan dengan fungsinya menanamkan nilai-nilai moderasi dan toleransi. Hal tersebut dapat diwujudkan melalui kurikulum dan proses pembelajaran, pengawasan dan pendampingan kegiatan di luar kulikuler serta melalui kebijakan lembaga.

\section{Daftar Pustaka}

Al Qurtuby, Sumanto, 2019, "Pacifying The Radicals: Religiuos Radicalism, Islamist Militancy and Peacebuilding Approaches in Contemporary Indonesia" Journal of Southeast Asian Studies, Volume 24(1).

Anonim, "Standardization of Pesantren aimed at Mainstreaming Moderate Islam", The Jakarta Post.

Asy'arie, Aziz, 2019, "Studi Fenomenologi Pengalaman Hijrah Mahasiswa Universitas Gadjah Mada dan Implikasinya Terhadap Ketahanan Pribadi" Master Thesis, Pascasarjana UGM.

Azra, Azyumardi, "Konservatisme Islam", Republika.co.id.

Bertrand, Jacques, \& Jessica Soedirgo, 2016, "A Threat to Stability? Islamic Extremism and Fundamentalism in Indonesia", CIGI Papers, No. 95.

Bruinessen, Martin Van, 2011, "What Happened to the Smilling Face of Indonesian Islam? Muslim Intellectualism and the Conservative Turn in Post-Suharto Indonesia" RSIS Working Paper.

, 2013, Contemporary Development in Indonesian Islam: Explaining the Conservative Turn, Singapore: ISEAS Publishing.

\footnotetext{
33 Mukhlis Dinillah, "ITB Bekukan Organisasi Mahasiswa yang Syiarkan Negara Khilafah", news.detik.com, diakses pada 14 Oktober 2019 pada pukul 06.30 WIB.
} 
Dinillah, Mukhlis, "ITB Bekukan Organisasi Mahasiswa yang Syiarkan Negara Khilafah", news.detik.com.

Hanafi, Muhlis M., 2016, Islamic Moderatism and Its Role in Empowering Harmony within Society, Jakarta: Lajnah Pentashihan Mushaf Al Qur'an Balitbang dan Diklat Kemenag RI.

Hefner, Robert W., 2000, Civil Islam: Muslims and democratization in Indonesia, Princeton: Princeton University Press.

2019, "Whatever Happened to Civil Islam? Islam and Democratisation in Indonesia, 20 Years on", Asian Studies Review, DOI: 10.1080/10357823.2019.1625865.

International NGO Forum on Indonesia Development, 2018, Urgensi dan Strategi Efektif Pencegahan Ekstremisme di Indonesia, Jakarta: Infid.

Kamdani (ed), 2007, Islam dan Humanisme: Aktualisasi Humanisme Islam di Tengah Krisis Humanisme Universal, Yogyakarta: Pustaka Pelajar.

Kementerian Agama RI, 2019, Moderasi Beragama, Jakarta: Badan Litbang dan Diklat Kemenag RI.

LPPM UNUSIA, 2019, "Islam Eksklusif Transnasional Merebak di KampusKampus Negeri”, Ringkasan Laporan Penelitian.

Nuralam, Candra Yuri, "Kelompok Islam eksklusif Leluasa Bergerak di Kampus" medcom.com.

PPIM UIN Jakarta, 2018, "Ancaman Radikalisme di Sekolah", Policy Brief Series, Issue 4, Vol. 1.

Rahmat, M. Imdadun, 2005, Arus Baru Islam Radikal: Transmisi Revivalisme Islam Timur Tengah ke Indonesia, Jakarta: Erlangga.

Schmid, Alex. P., 2017, "Moderat Muslim and Islamist Terrorism: between Denial and Resistance" ICCT Research Paper, DOI: 10.19165/2017.1.09.

Sebastian, Leonard C. \& Alexander R Arifianto, 2017, "From Civil Islam Toward NKRI Bersyariah? Understanding Rising Islamism in PostReformasi Indonesia" ASSEHR, Volume 129.

Setara Institute, 2019, "Wacana dan Gerakan Keagamaan di Kalangan Mahasiswa", Ringkasan Eksekutif.

Setijadi, Charlotte, 2017, "Ahok's Downfall and the Rise of Islamist Populism in Indonesia" ISEAS Yusof Ishak Institute, No. 38.

Woodward, Kathleen E., 2015, "Indonesian School: Shaping the Future of Islam and Democracy in a Democratic Muslim Country" Journal of International Education and Leadership, Vol. 5 Issue 1. 
Yakin, Ayang Utriza, 2016, Islam Moderat dan Isu-Isu Kontemporar, Jakarta: Kencana.

Yunanto, Sri, 2018, Islam Moderat vs Islam Radikal; Dinamika Politik Islam Kontemporer, Yogyakarta: Media Pressiondo.

Zuhdi, Muhammad, 2018, "Challenging Moderate Muslim: Indonesia's Muslim School in the Midst of Religious Conservatism" Journal Religions. 